\title{
Complex analysis of stationarity and homogeneity of flash flood maximum discharges in the Rika River basin
}

Liudmyla Gorbachova,

\section{Tetiana Bauzha}

Ukrainian Hydrometeorological Institute of the National Academy of Science of Ukraine and of the State Emergency Service of Ukraine,

37 Nauki Prospect,

Kyiv-28, 03028, Ukraine

E-mail: lyudgor@list.ru
An important hydrological task for flood dangerous regions of any country is an analysis of maximum flow trends of rivers because in these areas high floods of different genesis with significant and long-term flooding of the territories, sometimes with catastrophic consequences, have formed. In Ukraine the Carpathian Mountains belong to such regions.

In the article, an analysis of long-term dynamics of maximum discharges of mountain rivers in the Rika River basin (Ukrainian Carpathian Mountains) was presented. Research of the maximum discharges of the flash floods that are 1.6 times higher than the maximum discharges of snow-rain floods on average in the basin is carried out. Complex use of hydrological genetic (total and difference integral curves, compatible chronological graphs) and statistical methods (statistical significance of linear trends, Fisher's and Student's statistical criteria) for the estimation of homogeneity and stationarity of observation series for the achievement of more reliable results was researched. The cyclical fluctuations of the maximum discharges of flash floods are analyzed.

Key words: maximum discharge, small mountain catchments, stationarity, homogeneity

\section{INTRODUCTION}

Flash floods in the Carpathian Rivers are the largest in Ukraine in height and intensity, and they are observed several times a year. Due to intense rains the floods are dangerous, sometimes even catastrophic, and they cause considerable damages not only to the economy (flooding lands, granaries, destruction of roads, bridges and other engineering communications) but also to human life. Sometimes stormy rainfall floods can be observed not only on large and medium rivers but also in small mountain watercourses. The values of the maximum discharges of the flash floods are very often exceeding floods of snowmelt water because the water yield during rainstorms is much more intense than during snowmelt. Therefore, analysis of trend changes of the maximum discharges of the flash floods has scientific and practical importance.

The present researches of the maximum flow in the rivers of the Ukrainian Carpathian are being carried out by numerous authors. For example, an analysis of the flood flow in the Tysa River basin has been carried out by Gopchenko, Grebin, Susidko, et al. [1-5]. However, any research of the maximum flow for small rivers has not been carried out. Therefore, the goal of this paper is a complex 
analysis of the maximum flow of the flash floods in small and medium rivers in the upper part of the Rika River basin and calculation of their statistical characteristics. The complex analysis includes the use of the hydrological genetic and statistical methods of the research of the observed data and the comparison of the results.

The main tasks of the research are as follows:

- estimation of the homogeneity of the flood discharges by the total integral curve and Fisher and Student statistical criteria;

- estimation of the stationarity of long-term fluctuations of the maximum discharges of the flash floods by an assessment of statistical significance of linear trends;

- analysis of the difference integral curves of the observation series to reveal the regularity of cyclical fluctuations of the maximum flow;

- determination of statistical hydrologic characteristics of the maximum discharges of rivers and streams;

- definition of the phases of cyclical fluctuations of the water discharges in the Rika River basin.

\section{DATA AND METHODOLOGY}

The observation data from 16 water gauging stations were used for the research: 4 small $\left(F_{\text {basin }}=10-100 \mathrm{~km}^{2}\right)$ and 2 medium $\left(F_{\text {basin }}=100-1000 \mathrm{~km}^{2}\right)$ rivers (according to the classification of the EU Water Framework Directive 2000/60/EC), and 5 streams within the Zacarpatska Waterbalance Station (ZWBS). The research object and water gauging stations (WGS) are presented in Fig. 1. The period of observation on these water bodies is from 47 to 50 years (Table 1). The ZWBS is located in the upper part of the Rika River basin (the right tributary of the Tysa River) with the closing water gauging station in the Mizhgirya Village $\left(F_{b a s i n}=550 \mathrm{~km}^{2}\right)$ (the western part of Ukraine) and occupies the south-west slopes of the East Carpathians within the heights from 434 to $1599 \mathrm{~m}$ above the sea level. The river network is presented by ten rivers (Rika, Rypynka, Lopushna, Golyatynka, Studenyy, Pylypets, etc.) with the length from 7.1 to $31.3 \mathrm{~km}$ and more 500 streams by the length from 2 to $3 \mathrm{~km}$. The catchment areas have changed in greater limits - from $10-15$ to $550 \mathrm{~km}^{2}$. More detailed characteristics of the study area are described in the paper [6].

Forming of the maximum flow of the flash floods (May-October) in the upper part of the Rika River is due to rainstorm or long-term steady rain. In the rivers and streams the flash floods were observed annually, but in particular years they were observed several times per year. These floods are characterized by significant height and intensity [5]. Sometimes the flash floods have catastrophic consequences.

The maximum discharges of the flash floods were obtained on the basis of complex graphs (discharge, air temperature, precipitation) for the calendar period of the year. In some years for some rivers and streams the observations are missing. Thus, the omissions in the observation data were restored by the method of pair

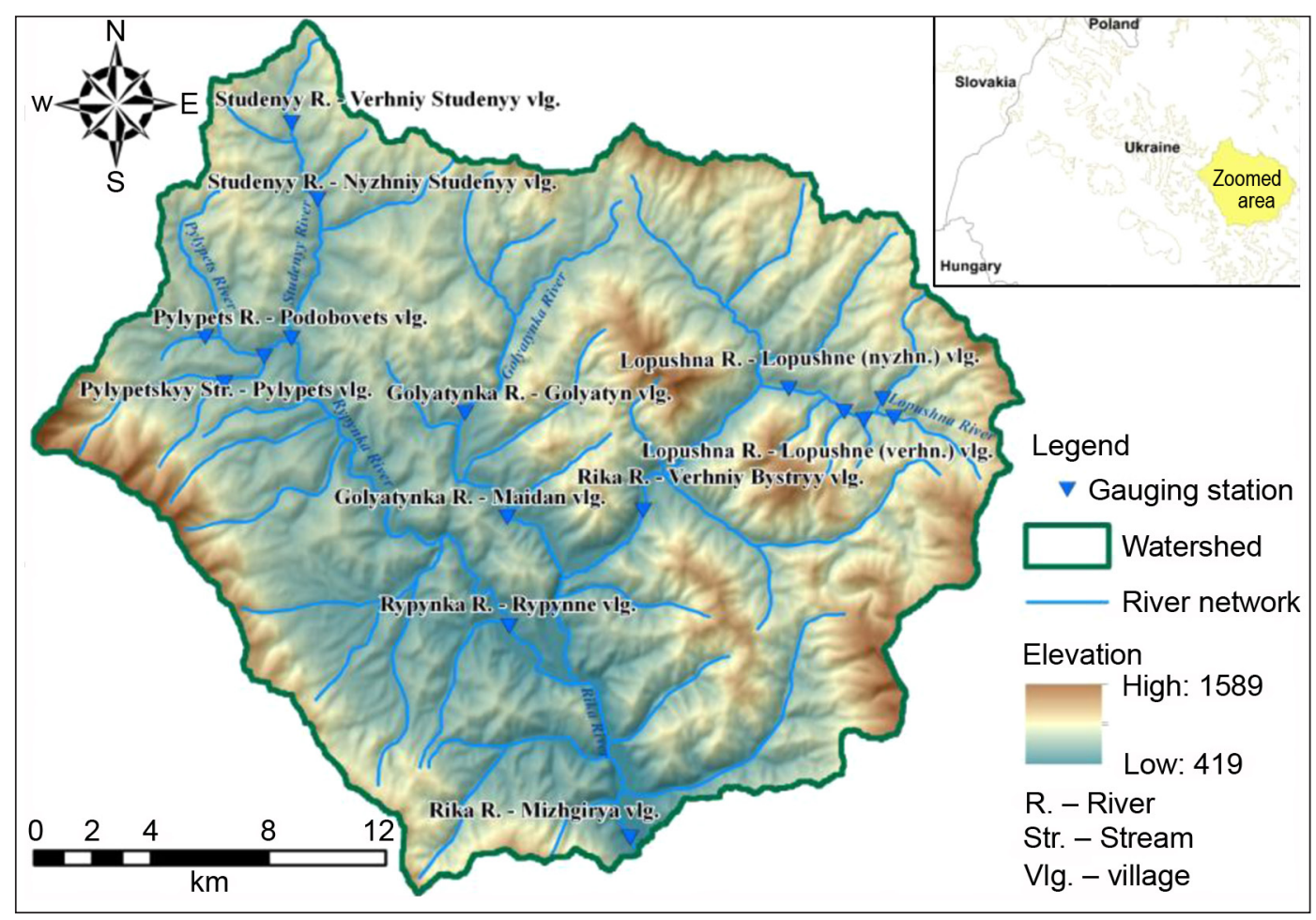

Fig. 1. The water gauging stations in the upper part of the Rika River basin 
Table 1. The autocorrelation coefficient of maximum discharges of the flash floods in the rivers and streams of the Rika River basin

\begin{tabular}{cccc}
\hline No. & Name of the water gauging station & Period & $r(\mathbf{1})$ \\
\hline 1. & Pylypets River - Podobovets Village & $1957-2006$ & 0.2 \\
\hline 2. & Pylypets River - Pylypets Village & $1957-2006$ & 0.1 \\
\hline 3. & Ploshanka Stream - Pylypets Village (nyzhn.) & $1957-2006$ & 0.1 \\
\hline 4. & Branysche Stream - Lopushne Village & $1960-2006$ & 0.1 \\
\hline 5. & Studenyy River - Verhniy Studenyy Village & $1957-2006$ & 0.0 \\
\hline 6. & Golyatynka River - Golyatyn Village & $1957-2006$ & 0.0 \\
\hline 7. & Golyatynka River - Maidan Village & $1957-2006$ & 0.0 \\
\hline 8. & Rika River - Mizhgirya Village & $1957-2006$ & 0.0 \\
\hline 9. & Rypynka River - Rypynne Village & $1957-2006$ & 0.0 \\
\hline 10. & Rika River - Verhniy Bystryy Village & $1957-2006$ & 0.0 \\
\hline 11. & Studenyy River - Nyzhniy Studenyy Village & 0.0 \\
\hline 12. & Pylypetskyy Stream - Pylypets Village & $1957-2006$ & 0.0 \\
\hline 13. & Lopushna River - Lopushne Village (nyzhn.) & $1959-2006$ & 0.0 \\
\hline 14. & Lopushna River - Lopushne Village (verhn.) & $1960-2006$ & 0.0 \\
\hline 15. & Zyubrovets Stream - Lopushne Village & $1960-2006$ & 0.0 \\
\hline 16. & Seredniy Zvir Stream - Lopushne Village & $1960-2006$ & 0.0 \\
\hline
\end{tabular}

regression by using the data of analogue streams and rivers and the HydroStatCal program developed in the State Hydrological Institute (Russia). This method consists of the calculation of the regression equation using the data of analogue rivers. The data were restored under such conditions [8]:

$$
R \geq 0.7, n \geq 10, \mathrm{k} / \sigma_{k} \geq 2,
$$

where $R$ is the correlation coefficient between the values of the maximal discharges in the research gauging station and an analogue gauging station; $n$ is the number of joint years of the observations in the research gauging station and an analogue gauging station; $k$ is the regression coefficient; $\sigma_{k}$ is the standard deviation of the regression coefficient.

The estimation of the statistical hydrologic characteristics is carried out by the homogeneous data to receive accurate and reliable results [7]. The estimation of the homogeneity and stationarity of the observation series of the flood discharges was carried out by hydrological genetic and statistical methods.

The hydrological genetic methods are the following:

1) total integral curves the forms of which (presence or absence of any turning-point in the directions of the curves) will allow to find the influence of anthropogenic factors and the climate change on the formation of the river runoff; 2) difference integral curves that will allow to reveal the regularity in the cyclical fluctuations of the runoff in the catchment; 3) compatible chronological graphs.

The statistical methods are as follows:

1) statistical significance of the linear trends and 2) statistical criteria by the Fisher's (for dispersions) and Student's (for averages) test methods.
Estimation of the stationary of long-term fluctuations of the maximum flow is carried out by the assessment of statistical significance of linear trends [7]. In turn, statistical significance of the trends is defined by statistical significance of the correlation coefficient $(R)$. The correlation coefficient of this dependence is estimated by the relation to the standard deviation $\left(\sigma_{R}\right)[7]$ :

$$
R / \sigma_{R} \geq \beta .
$$

For $5 \%$ of the significance level or for the $95 \%$ confidential limit the value $\beta=2$. If in the result of the calculations $R>2 \sigma_{R}$, it will indicate no stationarity of the long-term fluctuations of the runoff, and, on the contrary, if $R<2 \sigma_{R}$, it is the homogeneity of the runoff in the course of time. The standard deviation of the correlation coefficient for $n>25$ is defined by the formula [7]:

$$
\sigma_{R}=\left(1-R^{2}\right) / \sqrt{n-1},
$$

where $n$ is the length of the data series.

A quantitative estimation of the homogeneity of the observation data is carried out by Fisher's and Student's generalization criteria which were developed in the State Hydrological Institute (Russia) [8] for 5\% significant level with use of their autocorrelation. The autocorrelation coefficient $(r(1))$ is defined as follows [8]:

$$
\begin{aligned}
& r(1)=\left[\sum_{i=1}^{n-1}\left(Q_{i}-\overline{Q_{1}}\right)\left(Q_{i+1}-\overline{Q_{2}}\right)\right] / \\
& \sqrt{\sum_{i=1}^{n-1}\left(Q_{i}-\overline{Q_{1}}\right)^{2} \sum_{i=2}^{n}\left(Q_{i}-\overline{Q_{2}}\right)^{2}}
\end{aligned}
$$

where $\bar{Q}_{1}$ and $\bar{Q}_{2}$ are defined as follows: 


$$
\begin{aligned}
& \overline{Q_{1}}=\left(\sum_{i=1}^{n-1} Q_{i}\right) /(n-1) ; \\
& \overline{Q_{2}}=\left(\sum_{i=2}^{n} Q_{i}\right) /(n-1),
\end{aligned}
$$

where $Q_{i}$ is the value of the maximum discharge of the flash flood in every year; $\bar{Q}$ is the average of the maximum discharges of the flash flood in a long-term period; $n$ is the length of the data series.

According to the criteria, the time series are divided into two equal parts. The averages $(\bar{x}$ and $\bar{y})$ and dispersions $\left(\sigma_{x}^{2}\right.$ and $\left.\sigma_{y}^{2}\right)$ are calculated for each part of series. These calculations are later used for estimation of the Student $(t)$ and Fisher statistics $(F)$. In a general form, they are as follows [8]:

- the criterion of homogeneity of dispersions:

$$
F=\frac{\sigma_{x}^{2}}{\sigma_{y}^{2}}
$$

(6) where $A_{i}$ is the value of $i$ - element of the series; $\bar{A}$ is the

- the criterion of homogeneity of averages:

$$
t=\frac{|\bar{y}-\bar{x}|}{\sqrt{n_{1} \sigma_{x}^{2}+n_{2}} \sigma_{y}^{2}} \sqrt{\frac{n_{1} \cdot n_{2}\left(n_{1}+n_{2}-2\right)}{n_{1}+n_{2}}},
$$

where $\sigma_{x}^{2}$ and $\sigma_{y}^{2}$ are the dispersions of the time series of the maximum discharges; $n_{x}$ and $n_{y}$ are the length of the first and second half series; $\bar{x}$ and $\bar{y}$ are the average values of the first and second parts of the series.

The calculated values of these criteria are compared with the critical values for $5 \%$ of the significance level. If the empirical value exceeds the critical value, it is considered as the disturbance of the stationarity for these observation series.

For comparison of the results, the graphs of the longterm dynamics were created using modulus coefficients $\left(K_{A}\right)$ according to the following equation [8]:

$$
K_{A}=A_{i} / \bar{A},
$$

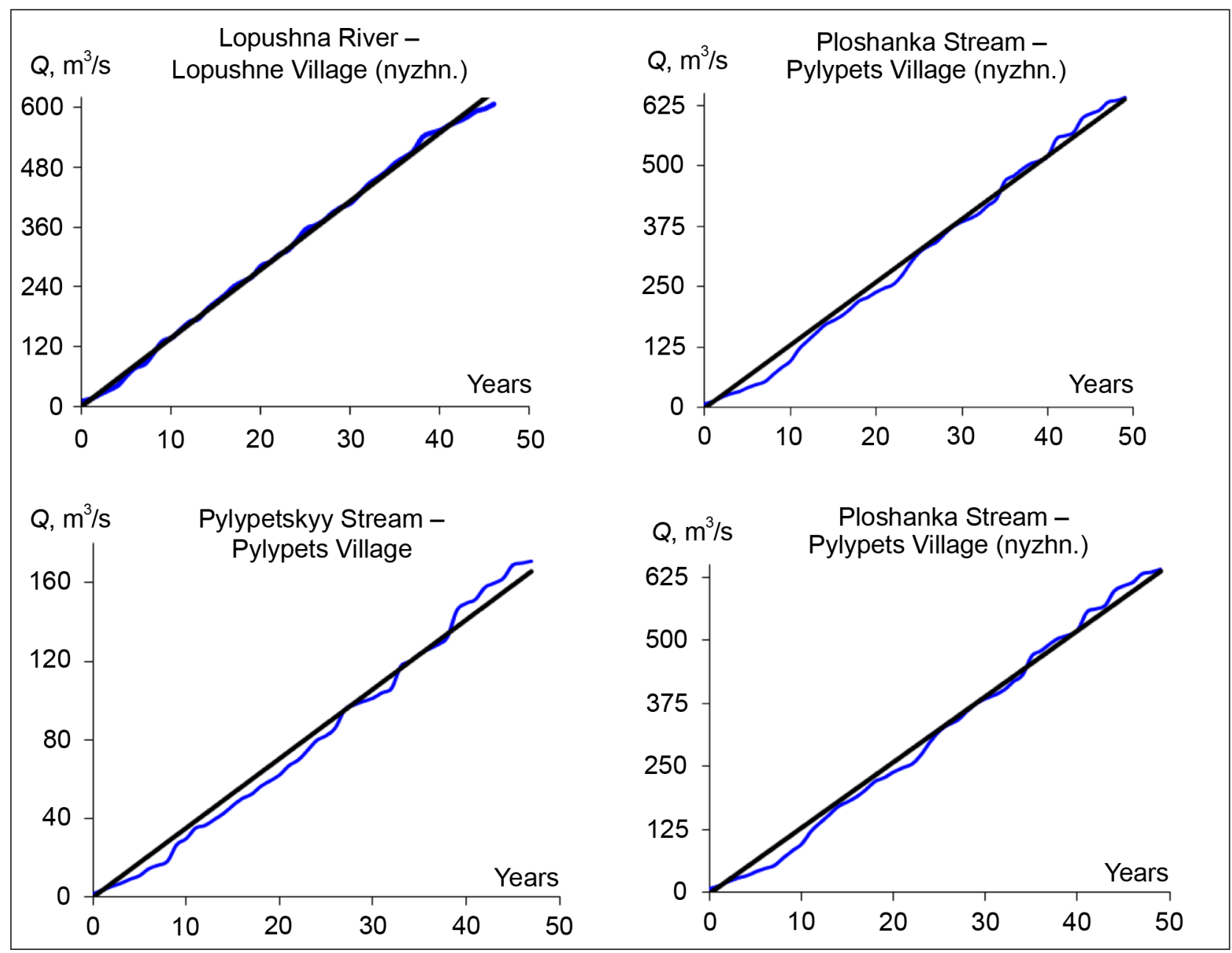

Fig. 2. Total integral curves of the maximum discharges of the flash floods in the rivers and streams of the Rika River basin 


\section{RESULTS}

Total integral curves of the flash flood maximum discharges were created for all rivers and streams of the ZWBS. They do not have any turning-point in the directions, i. e. the observation series from the start of observations till the end of 2006 are homogeneous. The examples of such curves are shown in Fig. 2.

An estimation of the homogeneity of the observation series of the maximum flow was carried out by the parametric statistical generalized criteria Fisher and Student taking into account the autocorrelation coefficient (Tables 1,2). The analysis in Table 2 has shown that the observation data in the water gauging stations Ploshanka Stream - Pylypets Village (nyzhn.), Pylypetskyy Stream - Pylypets Village, Golyatynka River - Golyatyn Village and Zyubrovets Stream - Lopushne Village are inhomogeneous for the Fisher criterion.

At the same time, the estimation of the stationarity of long-time fluctuations of the maximum discharges of flash floods by the statistical value of the linear trend for $5 \%$ significant level has shown that in all WGS the observation data are stationary (Table 3).

The synchronous fluctuations of the maximum discharges of flash floods are observed in all water gauging

Ta ble 2. Results of the homogeneity of the maximum discharges of the flash floods in the Rika River basin by parametric statistical generalized criteria Fisher $(F)$ and Student $(t)$

\begin{tabular}{|c|c|c|c|c|c|c|}
\hline \multirow{2}{*}{ Name of the water gauging station } & \multirow{2}{*}{$t$} & \multirow{2}{*}{$t_{\kappa p}$} & \multirow{2}{*}{$\boldsymbol{F}$} & \multirow{2}{*}{$\boldsymbol{F}_{k p}$} & \multicolumn{2}{|c|}{ Checking results } \\
\hline & & & & & Student & Fisher \\
\hline Rika River - Mizhgirya Village & 0.27 & 2.01 & 1.32 & 2.27 & + & + \\
\hline Rika River - Verhniy Bystryy Village & 0.24 & 2.01 & 1.40 & 2.27 & + & + \\
\hline Rypynka River - Rypynne Village & 0.05 & 2.01 & 1.39 & 2.27 & + & + \\
\hline Pylypets River - Podobovets Village & 0.05 & 2.42 & 1.55 & 2.34 & + & + \\
\hline Pylypets River - Pylypets Village & 0.53 & 2.20 & 1.21 & 2.29 & + & + \\
\hline Studenyy River - N. Studenyy Village & 0.92 & 2.01 & 2.14 & 2.27 & + & + \\
\hline Studenyy River - V. Studenyy Village & 0.43 & 2.01 & 1.16 & 2.27 & + & + \\
\hline Lopushna River - Lopushne Village (v) & 0.49 & 2.02 & 1.66 & 2.39 & + & + \\
\hline Lopushna River - Lopushne Village (n) & 0.28 & 2.02 & 1.04 & 2.39 & + & + \\
\hline Golyatynka River - Maidan Village & 1.14 & 2.01 & 2.00 & 2.27 & + & + \\
\hline Branysche Stream - Lopushne Village & 1.86 & 2.20 & 2.10 & 2.42 & + & + \\
\hline Seredniy Zvir Stream - Lopushne Village & 0.57 & 2.02 & 1.72 & 2.39 & + & + \\
\hline Golyatynka River - Golyatyn Village & 0.59 & 2.01 & 4.24 & 2.27 & + & - \\
\hline Zyubrovets Stream - Lopushne Village & 1.12 & 2.02 & 6.05 & 2.39 & + & - \\
\hline Ploshanka Stream - Pylypets Village (n) & 0.77 & 2.20 & 2.33 & 2.29 & + & - \\
\hline Pylypetskyy Stream - Pylypets Village & 1.18 & 2.02 & 4.05 & 2.39 & + & - \\
\hline
\end{tabular}

+- the homogeneous series of observations; - - the inhomogeneous series of observations.

Table 3. Linear trends of the maximum discharges of the flash floods of the watercourses in the Rika River basin

\begin{tabular}{|c|c|c|c|c|c|}
\hline Name of the water gauging station & Equations of the trends & $R^{2}$ & $R$ & $\boldsymbol{\sigma}_{R}$ & $2 \sigma_{R}$ \\
\hline Rika River - Mizhgirya Village & $Y=0.493 x-766.9$ & 0.00 & 0.06 & 0.14 & 0.29 \\
\hline Rika River - V. Bystryy Village & $Y=-0.001 x+2.22$ & 0.00 & 0.02 & 0.14 & 0.29 \\
\hline Rypynka River - Rypynne Village & $Y=0.002 x-3.20$ & 0.00 & 0.05 & 0.14 & 0.29 \\
\hline Pylypets River - Pylypets Village & $Y=-0.001 x+3.58$ & 0.00 & 0.03 & 0.14 & 0.29 \\
\hline Pylypets River - Podobovets Village & $Y=0.004 x-7.68$ & 0.01 & 0.08 & 0.14 & 0.28 \\
\hline Studenyy River - V. Studenyy Village & $Y=0.006 x-11.0$ & 0.01 & 0.09 & 0.14 & 0.28 \\
\hline Studenyy River - N. Studenyy Village & $Y=-0.002 x+4.21$ & 0.00 & 0.03 & 0.14 & 0.29 \\
\hline Golyatynka River - Golyatyn Village & $Y=-0.004 x+8.02$ & 0.01 & 0.08 & 0.14 & 0.28 \\
\hline Golyatynka River - Maidan Village & $Y=-0.007 x+14.9$ & 0.02 & 0.15 & 0.14 & 0.28 \\
\hline Lopushna River - Lopushne Village (n) & $Y=-0.003 x+6.46$ & 0.01 & 0.09 & 0.15 & 0.29 \\
\hline Lopushna River - Lopushne Village (v) & $Y=0.004 x-7.17$ & 0.01 & 0.09 & 0.15 & 0.29 \\
\hline Zyubrovets Stream - Lopushne Village & $Y=0.006 x-10.8$ & 0.01 & 0.11 & 0.15 & 0.29 \\
\hline Seredniy Zvir Stream - Lopushne Village & $Y=0.007 x-13.0$ & 0.01 & 0.10 & 0.15 & 0.29 \\
\hline Ploshanka Stream - Pylypets Village (n) & $Y=0.006 x-10.4$ & 0.02 & 0.14 & 0.14 & 0.28 \\
\hline Branysche Stream - Lopushne Village & $Y=0.009 x-17.2$ & 0.04 & 0.21 & 0.14 & 0.28 \\
\hline Pylypetskyy Stream - Pylypets Village & $Y=0.010 x-18.1$ & 0.04 & 0.19 & 0.14 & 0.28 \\
\hline
\end{tabular}




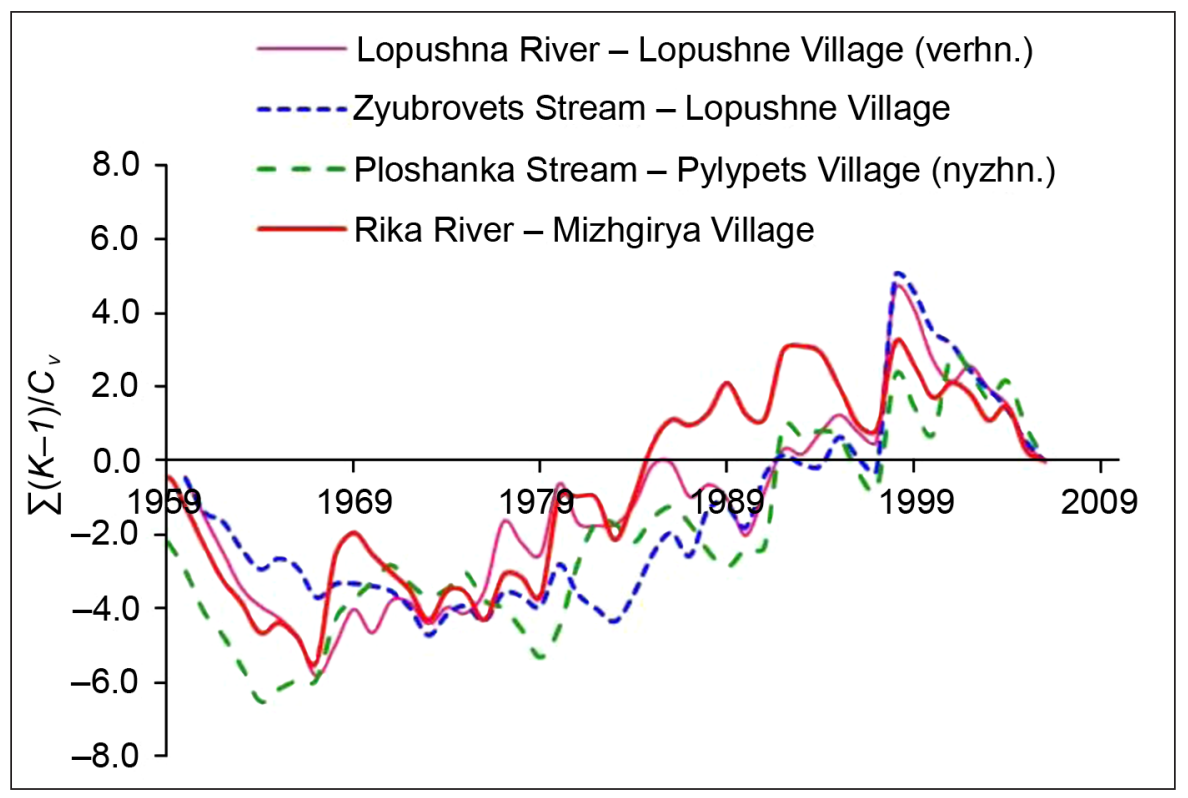

Fig. 3. Long-term dynamics of the maximum discharges of the flash floods in the Rika River basin

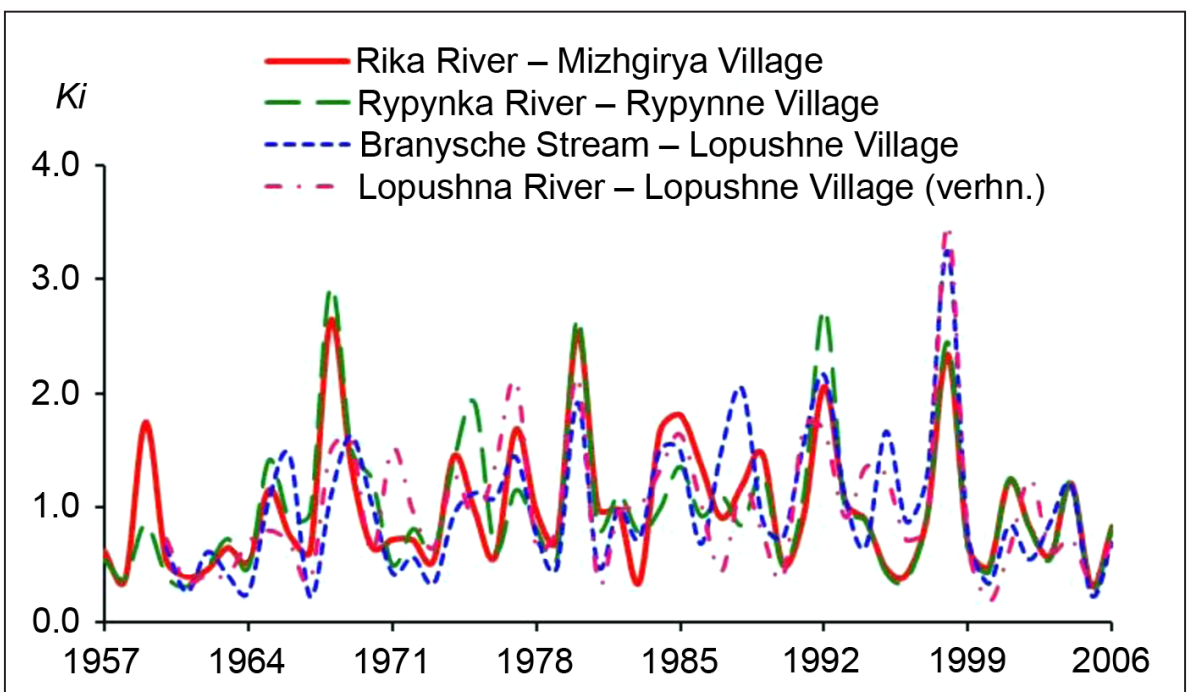

Fig. 4. Difference integral curves of the maximum discharges of the flash floods of the rivers and streams in the Rika River basin

stations. Therefore, the observation data are homogeneous because they have equal directions. The examples of such fluctuations for some rivers and streams are shown in Figs. 3 and 4.

Therefore, as a result of the above-indicated, the series of observations of the maximum discharges of the flash floods in the rivers and streams of the Rika River basin are homogeneous and stationary. The same results are received in the paper [9] but the analysis of the trends was conducted by one statistical method (non-parametric MannKendall test). Down analysis allows using the apparatus of mathematical statistics for further calculations. The definition of the statistical parameters of the maximum discharges was carried out by the three-parameter gamma distribution and binomial distribution using the method of the most probability or the method of moments with the HydroStatCal program.

The statistical parameters of the flash flood maximum discharges have changed in such range: the coefficients of variation $\left(C_{v}\right)$ - from 0.44 (Lopushna River - Lopushne Village (nyzhn.)) to 1.01 (Studenyy River - Verhniy Studenyy Village) and the coefficients of asymmetry $\left(C_{s}\right)$ - from 0.99 (Lopushna River - Lopushne Village (nyzhn.)) to 5.06 (Zyubrovets Stream - Lopushne Village) (Table 4).

The calculated probability characteristics of the maximum discharges of the flash floods will be corrected with prolongation of the observation series because the 
Table 4. Statistical parameters of the maximum discharges of the flash floods of the rivers and streams in the Rika River basin

\begin{tabular}{ccccccc}
\hline No. & Name of the water gauging station & $\mathbf{Q}_{\text {average }}$ & $\boldsymbol{C}_{\mathbf{v}}$ & $\mathbf{C}_{S} / \boldsymbol{C}_{\mathbf{v}}$ & $\boldsymbol{P}_{\boldsymbol{r}} \mathbf{1} \%$ \\
\hline 1. & Golyatynka River - Golyatyn Village & 37.2 & 0.68 & 6.52 & 150 \\
\hline 2. & Golyatynka River - Maidan Village & 43.7 & 0.70 & 4.56 & 158 \\
\hline 3. & Studenyy River - N. Studenyy Village & 14.9 & 0.86 & 4.60 & 70.5 \\
\hline 4. & Rypynka River - Rypynne Village & 84.5 & 0.62 & 3.17 & 274 \\
\hline 5. & Rika River - Mizhgirya Village & 210 & 0.59 & 3.35 & 644 \\
\hline 6. & Rika River - V. Bystryy Village & 47.2 & 0.49 & 4.58 & 128 \\
\hline 7. & Pylypets River - Pylypets Village & 30.0 & 0.69 & 3.94 & 106 \\
\hline 8. & Studenyy River - V. Studenyy Village & 6.61 & 1.01 & 4.25 & 36.1 \\
\hline 9. & Ploshanka Stream - Pylypets Village (n) & 12.8 & 0.59 & 3.88 & 40.3 \\
\hline 10. & Pylypetskyy Stream - Pylypets Village & 3.56 & 0.74 & 3.91 & 13.5 \\
\hline 11. & Pylypets River - Podobovets Village & 10.3 & 0.78 & 3.03 & 39.8 \\
\hline 12. & Branysche Stream - Lopushne Village & 5.09 & 0.60 & 2.34 & 15.2 \\
\hline 13. & S. Zvir Stream - Lopushne Village & 0.73 & 0.95 & 2.71 & 2.83 \\
\hline 14. & Lopushna River - Lopushne Village (v) & 6.00 & 0.60 & 2.96 & 18.7 \\
\hline 15. & Zyubrovets Stream - Lopushne Village & 1.50 & 0.83 & 6.09 & 7.18 \\
\hline 16. & Lopushna River - Lopushne Village (n) & 12.9 & 0.44 & 2.25 & 30.0 \\
\hline
\end{tabular}

researched data are not representative for definition of the average value (the absence of full cycle fluctuations) (Fig. 3).

The maximum flow of the flash floods of the rivers and streams in the studied region is characterized by three periods: 1) the phase of decrease of maximum discharges was from the start of observations till 1967;2) the phases of increase of flood discharges were from 1967 till 1998 and from 1967 till 1998; 3) the phase of flood decrease has been from 1998 to the present time (Fig. 3).

\section{CONCLUSIONS}

The observation data of the maximum discharges of the flash floods in the Rika River basin are homogeneous because the analysis of total integral curves does not have any significant turning-point in the directions. The absence of statistical significant trends is indicated on the stationarity of such observation data.

Estimation of homogeneity and stationarity of hydrological observation data by statistical methods does not always allow getting reliable results. This can be explained by the particularity of hydrological data (asymmetry, cyclicity, presence of distribution laws which differ from normal ones), which do not take into account such methods as generalization criteria Fisher's and Student's and the estimation of statistical significance of linear trends. Therefore, when estimating homogeneity and stationarity of flow, preference should be given to hydrological genetic methods (total and difference integral curves, compatible chronological graphs) because they, unlike statistical methods, take into account conditions of formation of the hydrological characteristics of the flow.

Since 1998, the decreasing phase of cyclical fluctuations of the maximum flow of flash floods has been present in the Rika River basin.
The calculated statistical parameters of time series of the maximum discharges of flash floods will become more reliable in the presence of full hydrological cycle (phases of increase and decrease of water flow) in consequence of prolongation of the length data by observation in the water gauging stations.

Received 13 May 2013 Accepted 5 June 2013

\section{References}

1. Gopchenko E. D., Romanchuk M. E., Kharitonova A. S. The calculation of maximal runoff of rain flood of Zacarpathia rivers. Proceedings of VOSEU, 2010. Vol. 10. P. 181-186 (in Russian).

2. Grebin V. V. The present of the change of separate characteristics of the rain floods on the rivers of Ukraine. Hydrology, Hydrochemistry and Hydroecology. 2010. Vol. 2(19). P. 74-85 (in Ukrainian).

3. Susidko M. M., Polyakova S. O., Scherbak A. V. The catalogue of the characteristics of the rain and snowrain floods on the rivers of Carpathian Region for 1989-2002 years. Proceedings of UHMI, 2006. Vol. 255. P. 298-309 (in Ukrainian).

4. Bauzha T. O. Flood flow during the cold period in the Rika River basin and its calculated characteristics. Hydrology, Hydrochemistry and Hydroecology. 2012. Vol. 2(27). P. 73-80 (in Ukrainian).

5. Melnyk T. P. The general analysis, the ways and manners of the decision of the problems of the snow-rain floods of the territory in the Tysa River basin. Hydraulics and Engineering Hydrology. 2009. Vol. 63. P. 1-10 (in Ukrainian). 
6. Bauzha T. O., Gorbachova L. O. Estimation of the homogeneity of the average annual runoff of the rivers and streams of the Zacarpatska station. BALWOIS 2012, Proceedings of International Conference on Water, Climate and Environment, 28 May - 2 June, Ohrid, Republic of Macedonia. http://www.balwois.com/2012

7. The Methodological Recommendations for Assessment of the Homogeneity of the Hydrological Characteristics and Definition of their Calculation Values for the Nonhomogeneous Data. Saint Petersburg: State Hydrological Institute, 2010. P. 39-40 (in Russian).

8. BNR (The Building Norm and Rules 2.01.14-83). The Determination of the Calculation of Hydrologic Characteristics. State Committee USSR on the Construction, 1983. 97 p. (in Russian).

9. Zabaleta A. Regional hydrological signs for climate change (Basque Country). BALWOIS 2012, Proceedings of International Conference on Water, Climate and Environment, 28 May - 2 June, Ohrid, Republic of Macedonia. http://www.balwois.com/2012

Liudmila Gorbačiova, Tatjana Bauža

\section{LIETAUS POTVYNIŲ MAKSIMALIŲ DEBITŲ STACIONARUMO IR HOMOGENIŠKUMO KOMPLEKSINE் ANALIZE் RIKA UPĖS BASEINE}

\section{Santrauka}

Bet kurios šalies regionams, kuriems gresia pavojingi potvyniai, svarbi hidrologinè užduotis - analizuoti upių maksimalius debitus. Pavojingų potvynių regionams yra būdingi aukšti potvyniai su reikšmingais ir ilgalaikiais teritorijų užtvindymais, kartais turintys net katastrofiškas pasekmes. Ukrainoje esantys Karpatų kalnai kaip tik priklauso tokiam regionui.

Straipsnyje analizuojama daugiametė upių lietaus potvynių maksimalių debitų dinamika Rika upès baseine, nes staigių lietaus potvynių debitai yra 1,6 karto didesni nei sniego-lietaus poplūdžiai. Lietaus potvynių maksimalių debitų stacionarumo ir homogeniškumo analizė buvo atlikta naudojant hidrologinius (suminès ir diferencinès integralinès kreivès, chronologinių diagramų palyginimas) ir statistinius (tiesinių trendų statistinis reikšmingumas, Fisher ir Stjudent statistiniai kriterijai) metodus. Straipsnyje taip pat tiriami cikliniai potvynių maksimalių debitų svyravimai.

Raktažodžiai: maksimalus debitas, maži kalnų baseinai, stacionarumas, homogeniškumas
Людмила Горбачёва, Татьяна Баужа

\section{КОМПЛЕКСНЫЙ АНАЛИЗ СТАЦИОНАРНОСТИ И ОДНОРОДНОСТИ МАКСИМАЛЬНЫХ РАСХОДОВ ВОДЫ ДОЖДЕВЫХ ПАВОДКОВ В БАССЕЙНЕ РЕКИ РИКА}

Резюме

Для районов, которые являются опасными в гидрологическом отношении, т. е. характеризуются формированием паводков разного генезиса со значительным и продолжительным затоплением территорий, иногда с катастрофическими последствиями, важным заданием является анализ тенденций максимального стока рек. В Украине к таким районам относятся Карпатские горы.

В этой статье представлен анализ многолетней динамики максимальных расходов воды на горных реках в бассейне р. Рика (Украинские Карпаты). Исследование выполнено для максимальных расходов воды дождевых паводков, потому что такие расходы в среднем по бассейну в 1,6 раза превышают максимальные расходы воды снего-дождевых паводков. Рассматриваются актуальные научные и прикладные задачи: комплексное использование гидролого-генетических (суммарные и разностно-интегральные кривые, совмещенные хронологические графики) и статистических (статистическая значимость линейных трендов, критерии Фишера и Стьюдента) методов оценки однородности и стационарности рядов наблюдений с целью получения более достоверных результатов. Проанализированы циклические колебания максимального стока воды теплого периода года.

Ключевые слова: максимальный сток, малые горные водосборы, стационарность, однородность 